and I have observed only one misprint and two or three minor errors of fact. The price is not unreasonable on current standards, particularly having regard to the wealth of illustrations.

E. G. Cox

\section{OUR REMOTE PREDECESSORS}

Prelude to History

A Study of Human Origins and Palæolithic Savagery. By Adrian Coates. Pp. xviii $+289+3$ plates. (London: Methuen and Co., Ltd., 1951.) 22s. $6 d$ net.

$\mathrm{T}$

$\mathrm{HE}$ attitude of prehistorians to their subject has changed considerably in the past thirty years. As a result, many of the classic treatises are now out of date. Much more has actually been discovered, and there is more evidence available to back up intelligent guesses as to the outlook of the remote folk of prehistory in respect to matters for which no actual relics could survive. It is still true to say that we can with safety go no further than the implements will take us as regards "our fossil-forerunners" of lower palæolithic times; but when we come to "our forerunners" of the upper palæolithic and mesolithic epochs we can legitimately fill in many gaps-we can clothe to some extent the dry bones of factual evidence with flesh and blood. Of course, this is still more the case with "our ancestors" of the neolithic and early metal ages.

From time to time it is very necessary and refreshing to stand back and take stock of what is known as a whole-a task for which the professional specialist often knows too much of details, sometimes nearly irrelevant, and as a result any general book written by him tends to lack balance. Such a survey is best undertaken by an intelligent and really knowledgeable amateur of the subject: one who has read widely but whose nose is not so close to the wall-perhaps himself adding brick to brick of knowledge - that he cannot see the proportions and scope of the edifice itself. The author will need a selective judgment, an eye for essentials, if his survey is to convey a correct impression. To my mind, such a book is to be found in "Prelude to History", and Adrian Coates is to be congratulated on having written it. The work is well illustrated and gives a very good picture of what is now known of human life and habits before neolithic times. An attempt, too, has been made to link up the various cultures with the type of folk who evolved them, and the small sketches of the various skull forms are not the least valuable part of the work.

After a short foreword by my colleague and former pupil, Dr. G. E. Daniel, there is a general introduction, and next the stage is set upon which the various cultures of western Europe will play their parts. This naturally involves some geological considerations, but these questions are dealt with in a simple manner. The problems of the evolution of man and early palæolithic times are next considered, and the way is then cleared for an account of late palæolithic cultures, the various racial groups concerned, and the wonderful art of this period. A chapter on the primitive mind and another on primitive society follow. Here, of course, the author passes more into the realm of the hypothetical. But there is much food for thought in this part of the book. Finally the author leaves the hunting economy and con- siders the relationship between the older food collectors and their food-producing successors.

As I have said, "Prelude to History" gives a very useful general picture of the subject and embodies the modern approach to the study of these remote peoples.

M. C. BurkitT

\title{
FIELD CROPS IN THE UNITED STATES
}

\section{Field Crops}

By Howard C. Rather and Prof. Carter M. Harrison. (McGraw-Hill Publications in the Agricultural Sciences.) Second edition. Pp. ix +446 . (London : McGraw-Hill Publishing Co., Ltd., 1951.) $47 s$.

YROP husbandry is a large enough subject in 1 Great Britain; in the United States, with a much longer list of cultivated crops and the additional complications arising out of soil erosion, farm crops or agronomy covers a formidable range. The second edition of this book by the late Prof. H. C. Rather and Prof. C. M. Harrison, of Michigan State College, brings up to date their account, originally published in 1942, of the essentials of crop husbandry in the United States. The book is addressed primarily to college students taking up the study of agronomy and those working in related fields who need to appreciate the broad principles of the subject. The material is presented in text-book form, each chapter being followed by a list of questions bearing closely on the subject-matter, and a set of problems requiring more thought and wider reading.

The subject is introduced by chapters dealing with soil conservation and management, including erosion control, fertilizers and rotation. This is followed by soil cultivation, and here the stress is laid on weed control. Several chapters are then devoted to the growth and management of legumes, forage crops and pastures, which depend fundamentally upon livestock, and this aspect of crop production is rightly given great prominence. To British readers who may be unfamiliar with United States agriculture, the relative importance of crops common to both countries such as alfalfa (lucerne), timothy grass, blue grass (Poa pratensis) and, in particular, white clover will be of interest. Of the last, the authors say that nearly all the white clover seed sown in the United States is used in lawn grass mixtures. It is interesting to note that no less than 21 million acres in the United States are devoted to seed production of six leading legumes and grasses, and a valuable chapter is devoted to this subject.

The remainder of the book deals with the important cereal, root and industrial crops, including cotton, sugar crops and tobacco, a useful feature being a series of maps showing their distribution throughout the United States. The material is carefully selected, much of it from the extensive literature issued by the State colleges, and references are given to some of the more important publications.

The book gives an excellent view of a subject that is continually developing in mechanization, weed control and crop improvement. It does not overlook the impact of practical farm affairs and economic forces which are at least as important as technical advances. It is well illustrated and has an adequate index. 